\title{
Determinants of Working Capital Investment and Financing Policy: Evidence from Trading and Service Sector in Malaysia
}

Noryati Ahmad, Mohammad Shahril Isahak, Fahmi Abdul Rahim

To Link this Article: http://dx.doi.org/10.6007/IJARAFMS/v11-i3/10978 DOI:10.6007/IJARAFMS /v11-i3/10978

Received: 07 July 2021, Revised: 13 August 2021, Accepted: 29 August 2021

Published Online: 20 September 2021

In-Text Citation: (Ahmad et al., 2021)

To Cite this Article: Ahmad, N., Isahak, M. S., \& Rahim, F. A. (2021). Determinants of Working Capital Investment and Financing Policy: Evidence from Trading and Service Sector in Malaysia. International Journal of Academic Research in Accounting Finance and Management Sciences, 11(3), 500-522.

Copyright: @ 2021 The Author(s)

Published by Human Resource Management Academic Research Society (www.hrmars.com) This article is published under the Creative Commons Attribution (CC BY 4.0) license. Anyone may reproduce, distribute, translate and create derivative works of this article (for both commercial and non-commercial purposes), subject to full attribution to the original publication and authors. The full terms of this license may be seen at: http://creativecommons.org/licences/by/4.0/legalcode

Vol. 11, No. 3, 2021, Pg. 500 - 522

Full Terms \& Conditions of access and use can be found at http://hrmars.com/index.php/pages/detail/publication-ethics 


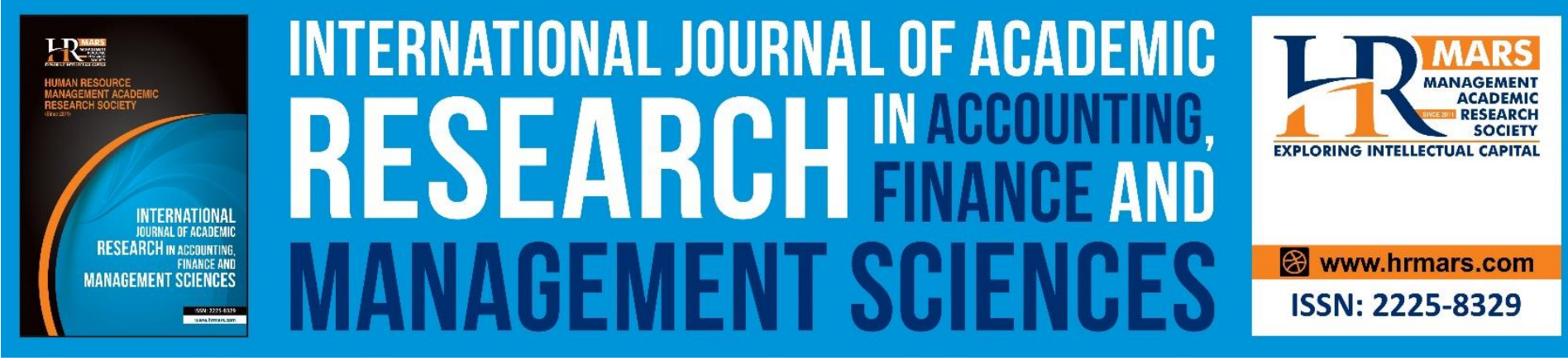

\title{
Determinants of Working Capital Investment and Financing Policy: Evidence from Trading and Service Sector in Malaysia
}

\section{Noryati Ahmad', Mohammad Shahril Isahak², Fahmi Abdul Rahim $^{3}$}

${ }^{1}$ Arshad Ayub Graduate Business School, Universiti Teknologi MARA, Puncak Alam,

${ }^{2}$ Department of Accounting, Faculty of Accounting, Universiti Teknologi MARA, Puncak Alam, Malaysia, ${ }^{3}$ Faculty of Business and Management, Universiti Teknologi MARA, Kampus Bandaraya Melaka, Malaysia

Email: noryatia@uitm.edu.my, shahrilisahak@uitm.edu.my,noryatia@uitm.edu.my, fahmi029@uitm.edu.my

\begin{abstract}
Despite the importance of managing the working capital effectively, research on this area is still meagre. The company has an option to either adopt a conservative or aggressive working capital management policy. However, what drives them to either use conservative or aggressive working capital policy remains unclear. By segregating into conservative and aggressive working capital management, the study provides better insight as to the motives for companies to do so. Thus, this paper intends to examine the driving factors leading companies in the Trading and Services sector to adopt conservative and aggressive working capital policies. Using secondary data, the study runs panel regression models over seven years from 2001 until 2017 on the companies of the trading and service sector. The identified independent variables are age, free cash flow, growth rate, leverage, profitability and size. Empirically findings reveal that all the identified independent variables are the determinants for adopting conservative working capital investment policy (CWCIP). Only leverage appears to affect the working capital management policies and is negatively related. In essence, there appear to be no specific dominant factors affecting the companies to adopt conservative or aggressive working capital investment and financing policy. Furthermore, it seems that the trading and services companies practice a targeted conservative/aggressive investment and financing policies since the lagged dependent variables are positive and statistically significant. This paper extends the existing growing but dearth literature on the determinants of working capital investment and financing policies. In addition, the results may be of interest to managers who are interested to understand the rationale for adopting a specific working capital policy. Future research should investigate the impact of working capital investment and financing policies on company performance and firm values. In addition, more research could be done to examine whether the industry effect influences the adoption of working capital investment and financing policies taken.
\end{abstract}


MANAGEMENT SCIENCES

Vol. 11, No. 3, 2021, E-ISSN: 2225-8329 @ 2021 HRMARS

Keywords: Working Capital Management, Investment Policy, Financing Policy, Conservative, Aggressive

\section{Introduction}

The firm capability to manage its working capital effectively will have a substantial implication for its liquidity and profitability (Shin \& Soenen, 1998). Pushpavathi and Kamalavalli (2017) stressed that non-optimal implementation of working management capital investment and financing policies are associated with inefficiency, high risk, poor company performance and ultimately bankruptcy. The company has an option either to implement a conservative or aggressive working capital management policy. A conservative working management policy focuses on a high level of current assets and a low level of current liabilities, while an aggressive working management policy entails a low level of current assets and a high level of current liabilities.

$\mathrm{Ng}$ et al (2017) pointed out that the economic recession in 2008 has made companies focus on efficient working capital management. Efficient working capital management leads to cash optimization. Price Waterhouse Corporation 2019 report on a working capital report revealed that despite an improvement in the cash conversion cycle of over 400 companies listed on Bursa Malaysia, about RM110 billion of cash was still being tied up. The ability to release this tied-up cash could help companies to boost their capital investment without having to seek additional funding externally and avoiding possible cash-flow problems. The report also highlighted that $60 \%$ of those companies prolong paying their accounts payables that subsequently resulted in supplies facing cash flow issues. Besides, they documented these companies are inefficient in managing their accounts receivable and payables where $70 \%$ of them have longer collection periods but shorter payment periods. Moreover, Ernst and Young (2016) also surveyed the performance of working capital of both large companies and small-medium enterprises for the United States, Europe, Asia, Australia \& New Zealand, Canada, Central and Eastern Europe, India, Japan and Latin America. The survey covered 2000 companies in the United States and Europe; and another 2000 companies from seven other sub-regions and countries. Despite showing an improvement in the working capital performance of large the US for 2015 relative to 2014 since cash conversion cycle has increased by $4 \%$ relative to 2014 while those in Europe show a drop of $2 \%$ in their cash conversion cycle. With US companies, it attributed the deterioration in working capital performance to more than half of those companies has poor inventory and payables management. In contrast, the good WC performance of large European companies resulted from good management in their receivables and inventory. Their report revealed that those non-performing companies are associated with their failure to address the major aspects of WCM policies. They proposed that most of the companies have the potential of improvement in the many aspects of WC especially in improving their profitability through the reducing of cash-to-cash or similarly average cash conversion cycle (how the company could turn cash into inventory and receivables and back to cash again in days). Variation in the performance of WC was also detected between various industries they found of which the pharmaceutical industry to have declined the most in its WC. As for the companies that are in Asia, companies from Malaysia, Singapore, South Korea and Taiwan showed an improvement in their working capital performance compared with 2014, while Japan posted the worse. For Malaysian companies, their average cash conversion cycle has improved from 59 days in 2014 to 55 days in 2015. However, compared to other countries like China, Taiwan and Thailand, Malaysia is 
MANAGEMENT SCIENCES

Vol. 11, No. 3, 2021, E-ISSN: 2225-8329 @ 2021 HRMARS

still considered to have a very high average cash conversion cycle (Ernest and Young, 2016). A high cash conversion cycle deprives companies of cash that could be applied to finance their operating activities and save companies from sourcing for external financing which could be rather expensive ( $\mathrm{Ng}$ et al., 2017). In short, the report concluded that working capital performance variations of these companies appeared to be affected by industry bias, different payment practices, and different logistics and distribution infrastructures.

Despite the substantial amounts of time that managers spent on establishing an optimal working capital policy, researches on working capital management have been the least studied (Palombini and Nakamura, 2012; Singh and Kumar, 2014). Singh and Kumar (2014) reviewed working capital management literature and discovered that academicians and managers have paid serious attention to working capital management only after the financial crisis of 2008. Over the past years, a dearth of studies has examined working capital management and preferred to focus on long-term aspects of finance such as capital structure, dividend, budgeting, investment and company valuation (Garcia, Martins and Brandao, 2011; Pais \& Gama, 2015). They added that these aspects have received greater attention because they involved main policies for the long run financial assistance. However, Supatanakornkij (2014) stated that WCM also plays a crucial role as it could increase companies' liquidity, profitability and firm value. Crump (2012) in his survey showed that several established firms could help survive because of lack of liquidity rather than profitability. It linked the WCM decision to long-term financing decisions. For example, a company with low inventories could affect its sales revenue and eventually it is operating profit margin and increases its operating leverage. This leads to the problem of the inability to pay interest on long-term debt, which eventually put the company in financial distress. Also, Smith (1973) explained that one reason for the company to fail is because of poor management of its current assets and current liabilities. Appuhamy (2008); Lamberson (1995) mentioned that the company could create value if the financial manager can manage efficiently its working capital. Furthermore, Zariyawati, Annuar and Pui San (2016) pointed out that the number of current liabilities will affect firm liquidity and the firm's financial condition if the firms ineffectively manage their working capital which subsequently leads to default. First, this research specifically examines determinants affecting the working capital management policies of Malaysian companies in the trading and service sector. The study differs from previous studies in the following manner. Negligible researches have directly addressed the driving factors of working capital management by using conservative and aggressive investment and financing working capital policy as the dependent variable. Numerous studies related to working capital management focus on the impact of conservative or aggressive policy on profitability. Understanding the factors affecting companies to embrace conservative and aggressive working capital investment and financing policies provides a better insight as to the motive to do so: how profitability is affected. In most past literature that investigate the determinants of working capital management, the proxies for the dependent variable (working capital management) are within the form of cash conversion cycle (CCC), working capital requirement and net trade credit policy. Using those proxies do not specifically show whether the factors affecting the working capital management affect the company's decision to be conservative and/or aggressive. In short, the empirical results do not segregate the working capital management into conservative and aggressive investment and financing policies, respectively. The researcher believes that investigating the determinants affecting the conservative and aggressive working capital policies would provide a clearer picture of the underlying reasons 
MANAGEMENT SCIENCES

Vol. 11, No. 3, 2021, E-ISSN: 2225-8329 @ 2021 HRMARS

for the company to adopt those policies. Hence this is the gap that the research intends to fill. Furthermore, through this research, not only the researcher can fill the gap as mentioned above but also more importantly expand toward a very important but neglected part of working capital management literature about a public listed Malaysian companies of trading and service sectors.

\section{Literature Review}

Working capital management policy is selecting the portion of current assets and (or) current liabilities to run the business (Kasiran, Mohamad and Chin, 2016). Effective working capital management ensures continuity of the firm's day-to-day business operations: The firm's value, risk and profitability are shaped by how a business manages its working capital. Gill and Biger (2013) put forward that firms could fall into insolvency or bankruptcy because of inappropriate control over working capital.

The terms aggressive and conservative WCM is used to indicate the relative degree of currents assets invested or short-term financing being sourced by the company in managing its working capital. The company that practises a conservative (aggressive) working capital investment policy usually is said to have a very high (low) level of investment in current assets (Nazir and Afza, 2009). A conservative (aggressive) working capital financing policy simply implies the management preference to use a high degree of long-term debt (short-term) to fund the investment of its current assets (Weinraub and Visscher, 1998). Working capital investment policy (WCIP) is measured by total current assets over total assets. A higher (lower) WCIP ratio implicates a relatively high degree of conservative (aggressive) WCIP. On the other hand, working capital financing policy (WCFP) is computed by total current liabilities divided by total assets. Management is considered to be conservative (aggressive) in its financing policy if the calculated WCFP is relatively lower (higher) in comparison to the industry CL/TA means.

Weinraub and Visscher (1998) measured the degree of conservative working capital working investment policy (CWCIP) by comparing it with the company's current asset to a total asset (CA/TA) means relative to the industry CA/TA means. A higher ratio implies a relatively more conservative WCIP (CWCIP). Companies in volatile or seasonal industries might adopt a conservative WC approach, as their risk is lesser compared to the aggressive WC approach. Conservatively managed working capital help the firm to lower the risks of short-term cash shortages, but it might also reduce long-term profitability because excess cash does not earn much of a return. Conversely, a conservative policy decision might indicate that some of your working capital may not be fully utilised. This is like leaving excess money unproductively instead of making it more profitable, for example by investing it in more strategic places.

On the other hand, aggressive working capital investment policy (AWCIP) results in a minimal level of investment in current assets versus total assets. This suggests that the firm has a low level of current assets investment. (Bandara, 2015, Panigrahi, 2014; Javid and Zita, 2014; \& Temtime, 2016). The goal is to put as much money to work as possible to reduce the time needed to produce products, turn over inventory or deliver services. This speeds up the firm's business cycle and improves sales and revenues. This leads to little money for usage, as the firm needs to cut back on slow-moving inventory and unnecessary supplies and extend bill payments for as long as possible. However, the firm should not postpone the interest payment as creditors can sue the firm, force them into bankruptcy and liquidate firms' assets. Another possibility is that firm could miss tax payments, as less cash is available to the 
MANAGEMENT SCIENCES

Vol. 11, No. 3, 2021, E-ISSN: 2225-8329 @ 2021 HRMARS

business. A relatively aggressive policy decision implies that the company has a lower WCIP mean ratio relative to the industry.

The company takes a conservative working capital financing policy (CWCFP) when it predominantly finances all its permanent current assets and most of its fluctuation current assets (temporary current assets) using the long-term source of finance. Only a smaller portion of its fluctuating current assets are financed using a short-term source of finance (AlShubiri, 2011). In short, this approach indicates that the company uses fewer current liabilities, but the emphasis is more on long-term debt to finance its assets. A lower WCFP ratio relative to the industry average denotes that the company is adopting a relatively more conservative financing (CWCFP) approach where more long-term debt is used rather than short-term debt. An aggressive working capital (AWCFP) approach from the financing perspective focuses on sustaining a higher ratio of total current liabilities to total assets. It is also linked with higher return and higher risk, as opposed to the conservative working capital approach that stress on reducing the risk and return (Al-Shubiri, 2011; Panigrahi, 2014). The risk of default and bankruptcy of a company increases as the more aggressive working capital approach is adopted. For instance, an unexpected situation might cause a firm unable to make a bond or bank interest payment. Minimal inventories can lead to shortages and even lost sales opportunities. Creditors might complain of having to extend credit further if firms stretch out or delay their payments. A company with a higher AWCFP ratio in comparison to the industry mean is said to be relatively aggressive in its working financing policy.

Unlike the determinants of capital structure, there are no specific theories found to explain the driving factors of working capital management. However, other studies like Azeem and Marsap (2015); Cuong and Nhung (2017); Nyeadi, Sare and Aawaar (2018) and Wasiuzzaman and Arumugam (2013) among others have referred to Jensen's free cash flow hypothesis, risk and return theory and agency theory to explain the factors affecting working capital management. The theory of risk and return suggests that a high level of working capital investment lead to low risk but also gives lower profitability. Khan et al (2016) state that managing this trade-off between risk and return is an important component of WCM. Firms may reduce their risk by holding more current assets, such as investing in larger cash and marketable securities balances. Holding larger cash and marketable securities balances has an unfortunate consequence because investments in cash and marketable securities earn relatively unsure returns. Compared to the firm's other investments, the firm that holds larger investments in current assets will reduce its overall rate of return. The firm's use of current versus long-term liabilities also involves risk and return issues. Using current liabilities can be less costly than long-term financing. However, for some reason, certain firms have problems raising short-term funds or they should need funds for longer than expected, which can get into real trouble. Thus, a firm can reduce its risk of illiquidity using long-term debt at the expense of a reduction in its return on invested funds. As a result, the risk-return trade-off involves an increased risk of illiquidity versus increased profitability (Keown et al., 2007).

Agency theory that is typically being used in determinants of capital structure decisions has also been used to explain the rationale for adopting conservative or aggressive working capital investment policies. In the interest of the shareholders, managers adopt an aggressive working capital investment policy. With a minimal amount of current assets, the firm will have higher profits available to shareholders in terms of dividends. As for taking an 
MANAGEMENT SCIENCES

Vol. 11, No. 3, 2021, E-ISSN: 2225-8329 @ 2021 HRMARS

aggressive financing policy, the company will resort to less use of debt financing. This approach will cause a lower agency problem.

Under Jensen's (1989) free cash flow hypothesis, it proposed that firm might decide to have a high level of cash to accumulate more assets. Having more cash enable them to be in control and have an advantage in investment decisions. This resulted in the cash-rich companies avoiding being in financial distress position and ultimately into bankruptcy. However, Wasiuzzaman and Arumugam (2013) pointed out that having too much cash could also put the company at a disadvantage. This is because having high liquidity situation will not force management to perform well for their company and therefore invest in unprofitable projects that do not have benefits. In brief, this theory implies that a company with excess cash will probably have a higher level of current assets, which end in agency costs on its working capital investment policy.

At the time the study is conducted, there is still very scant literature that examines working capital management in terms of conservative or aggressive working capital investment policy as its dependent variable. Previous studies used different measurements as a proxy for working capital management like cash conversion cycle, networking requirement and net working capital as the dependent variable Nazir \& Afza, 2009; Mansoori \& Muhammad, 2012; Mathuva, 2014). Empirical findings revealed that age, free cash flow, growth, leverage, profitability and size are the driving factors affecting working capital management. This study will use these independent variables to investigate whether they affect the conservative or aggressive working capital investment and financing policy.

\section{Firm Age}

Several studies found the age of the firm to be one factor of WCM. In most cases, the empirical evidence shows no clear direction between the two variables. Using net working capital (NWC) as a measure of working capital management, Wasiuzzaman and Arumugam (2013) studied the relationship of age and WCM on 192 non-financial firms from various industries listed on Bursa Malaysia for the year 1996 to 2007. The authors discovered young firms invested more in their WC so that they can improve sales growth. This is like the study of Hassan, Imran, Amjad and Hussain (2014) where they found the negative relationship between age and profitability of Pakistan firms listed on the Karachi Stock Exchange, but they find this association insignificant.

Contrary to the studies above, Chiou, Cheng and Wu (2006)'s study reveals a direct relationship between the age of a firm and WCM. They concluded that since matured companies are in better conditions, they, therefore, pay less attention to the management of their working capital. Young companies need to pay more attention to their WCM because they still have high growth opportunities, which require higher investment in working capital (Wasiuzzaman and Arumugam, 2013). Iftikhar (2013) examined nine automotive and engineering listed firms on the Karachi Stock Exchange in Pakistan from 2006 to 2010. Using the number of years since it incorporated the company as the measurement for the age of the firm; his study shows that the age of a firm contributes only a minor effect on WCM. The result concurs with those of Khan et al (2016).

According to Jensen and Meckling (1976), high free cash flow is usually associated with the inefficiency of management through unnecessary spending on unnecessary projects or investments, and this can hence increase the costs. Besides, it is agreed that agency costs may increase through the loss of some investments. Using the agency theory, McMahon (2006) explains that the company with excess free cash flow usually engage in projects with a 
MANAGEMENT SCIENCES

Vol. 11, No. 3, 2021, E-ISSN: 2225-8329 @ 2021 HRMARS

negative present value that leads to poor control by management. Ozkan and Ozkan (2004) suggested that firms with more unpredictable cash flows are expected to hold more cash in order $t$ to lessen the expected costs of liquidity constraints. The greater the firm's cash flow inconsistency, the greater the number of states of nature in which the firm will be short of liquid assets. Thus, firms with more unstable cash flows face a higher probability of experiencing a cash shortage because of unexpected cash flow deterioration (Ferreira and Vilela, 2004). Haron and Nomran (2016) found that free cash flow is directly related to the cash conversion cycle (CCC) only during the crisis condition. Supatanakornkij (2015) discovered that firm that has higher operating cash flow will invest more in working capital. Mansoori and Muhammad (2012) using CCC as measured of WCM found a significant negative relationship between operating cash flow. In contrast, Nazir and Afza (2009) found a direct relationship between cash flow and WCM.

\section{Firm Size}

Previous studies pointed out the size of a company also affected that WCM. Larger firms have better access for bulk purchases and they could even negotiate for better credit term which is longer from the suppliers. The bigger size of a company also suggests that they need more inventories to cater to the demand from customers. There are lots of studies regarding the size of the firm associate with working capital management (WCM). Salawu and Alao (2017); Onaolapo and Kajola (2015) observed a direct relationship between size and working capital (WC). The firm size was measured by the natural logarithm of sales, and WC was measured by working liquid assets minus liquid liabilities. They selected 60 sample firms from 12 various industries listed in the Nigerian Stock Exchange as the last samples. The result shows that size has a significantly positive relationship with working capital. They argued firms with greater size have better financing alternatives, hence easily can pay for investment in working capital. However, when size is measured to CCC, the relationship turn to be inversely related. This means that the bigger the size of firms, the shorter the CCC and vice versa. However, Onaolapo and Kajola (2015) documented a positive relationship between size and WCM. They conducted a study on thirty non-financial firms listed in the Nigerian Stock Exchange from the period of 2004 to 2011. Using working capital requirement as a dependent variable where it is measured by the firm's net working capital deflated by total assets. The correlation results have shown a positive relationship between the size of the firms towards net working capital (NWA_TA). It is suggested, the bigger the size of a firm, the higher the investment into the working capital necessity.

\section{Firm Growth Rate}

The firm growth rate is another independent variable that has a relationship with working capital management (Nyeadi et al., 2018, Haron and Nomran, 2016; Salawu and Alao, 2014; Wasiuzzaman and Arumugam, 2013). Sales growth is usually used as a proxy for firm growth and is measured as the current year's sale minus the previous year's sale divided by the previous year's sale. Since high sales growth needs more investment in inventories or working capital, it is assumed that sales growth has a positive relationship with WCM. Several studies have shown a positive relationship between firm growth and WCM (Wasiuzzaman and Arumugam, 2013; Salawu and Alao, 2014; Mansoori and Muhammad, 2012). Wasiuzzaman and Arumugam (2013) studied the relationship of growth with WCM. Non-financial firms from various industries listed on Bursa Malaysia from the period of 1996 to 2007 were taken as samples of the study. The results show a positive relationship between the growth of a firm 
MANAGEMENT SCIENCES

Vol. 11, No. 3, 2021, E-ISSN: 2225-8329 @ 2021 HRMARS

and WCM. It is highly significant, and its level is at $1 \%$. They argued that when the firm reached high growth in the previous year, it might pile up inventories in predicting future sales. They could achieve sales growth through credit granted to customers and therefore increase the account receivables. This led to an increase in working capital. Similarly, Salawu and Alao (2014) found that the firm's growth leads to an increase in working capital. In their research, it measured sales growth by current year sales minus last year sales divided by last year's sales, while WC is measured by working liquid assets minus liquid liabilities.

However, some studies have demonstrated different effects on the relationship between firm growth and WCM. A study by Zariyawati et al (2010) examined the determinants of WCM of 119 public listed Malaysian firms. Using the cash conversion cycle (CCC) as a proxy for WCM, their findings discovered a significant inverse relationship between a firm's growth on CCC. The result concurred with the study of (Moradi, Salehi and Arianpoor, 2012). They based their study on 34 chemical industries companies and 30 medicine companies listed on the Tehran Stock Exchange starting from 2001 to 2010.

There are also empirical results that suggested insignificant results such as Cuong and Nhung (2017), Mohamad and Elias (2013), Banos-Caballero et al (2010). Mohamad and Elias (2013) investigated seven different sectors in Malaysia comprise 150 public listed firms for the period of 2002 to 2011. Using correlation and Pooled Ordinary Least Square (POLS) regression analysis, their study detected no significant relationship between firms' growth with the working capital requirement. Onaolapo and Kajola (2015) have studied listed Nigerian firms and found that growth is negatively related to WCM. However, the result is not significant.

\section{Profitability}

Normally, the researcher uses ROA, ROE and Tobin Q to measure profitability. Most of the findings found that either one or more of these variables show(s) a positive relationship with WCM such as Fatimahtuzzahra and Kusumastuti (2016), Nazir and Afza (2009), Mansoori and Muhammad (2012), Wasiuzzaman and Arumugam (2013), Moussawi, LaPlante, Kieschnick and Baranchuk (2006) and others. Some studies found a negative relationship between ROA, ROE or Tobin Q with WCM such as Banos-Caballero (2014); Cuong and Nhung (2017); Haron and Nomran (2016) and Zariyawati et al (2016). In the meantime, Hill, Kelly and Highfield (2010) found no significant relationship between profitability and WCM. Apart from using ROA, ROE or Tobin Q, Ebenezer and Asiedu (2013) observed the relationship between working capital management and profitability by taking operating profit margin (OPM) as a measure of profitability that OPM acts as a dependent variable in their research. Another study by Javid and Zita (2014) also used OPM as their dependent variable and WCM components as independent variables. Contrarily, this study will use OPM as one determinant or independent variables to see the impact on aggressive or conservative WCM policies, as it is more relevant to the use of current assets and liabilities.

\section{Leverage}

Pecking order theory explained that firms could choose their internal fund or retained earnings before turning into debt as an option to source funds. This is because external financing is costly due to issuing costs as well as tight monitoring from investors. Based on this theory, leverage is said to have an indirect relationship with WCM. Azeem and Marsap (2015) used correlation and regression evaluation in their research on Pakistani non-financial companies listed in Karachi Stock Exchange and observed that leverage is negatively 
MANAGEMENT SCIENCES

Vol. 11, No. 3, 2021, E-ISSN: 2225-8329 @ 2021 HRMARS

correlated with WCR (a proxy for WCM). Besides, the study by Mohamad and Elias (2013) showed a negative relationship between leverage and working capital management and CCC (a proxy of WCM). They used data from 150 public Listed companies in Bursa Malaysia for the period 2002 to 2011 and working capital requirement and CCC as a proxy for dependent variables in this study.

In contrast, a study by Valipour, Moradi and Farsi (2012) on Iranian listed firms showed a positive relationship between leverage and CCC (as a proxy of WCM). They concluded that low leverage firms have a shorter period of keeping the inventory which results in a shorter CCC. There is also a positive and significant relationship that was found between leverage and WCR (measured as WCR_TA) by Gill (2011). The study used 166 manufacturing and services firms listed on the Toronto Stock Exchange as study samples and covering from the year 2008 to 2010. This study concluded that highly leverage firms should give more attention to handling WC to avoid too much capital being tied up in current assets such as account receivables and stocks. Besides, good management of WC is to avoid too many current liabilities as the cost of finance might increase and avoiding the risk of default.

Besides prior literature that has established a negative and positive relationship between leverage and size, some studies showed insignificant findings between the two. The results of the regression analysis of Mansoori and Muhammad (2012) study illustrated an insignificant relationship between leverage and CCC; as the leverage was used as one of the independent variables, measured by total liability divide by total assets and CCC (as a proxy of WCM) was measured by ARD plus ITD minus APD. This study involved 94 firms listed on the main board of the Singapore Exchange between the years 2003 to 2010. In another study, Ashhari, Hassan and Nassir (2010) examined 119 firms listed in Bursa Malaysia and the result showed that there is no significant relationship between leverage and WCM.

\section{Methodology}

The unit of analysis of this study is 134 companies from the trading and services sector for the year 2001 until 2017. For the working capital investment policy, the data was subdivided into conservative and aggressive investment policies adopted by the respective companies in the trading and services sector. Companies are said to have adopted a relatively conservative working capital investment policy (CWCIP) if the mean CA/TA ratio is greater than the industry means the CA/TA ratio. This implies that the company has a higher investment level of current assets. An aggressive working capital investment policy (AWCIP) is used if the company's mean CA/TA is lower than the industry means the CA/TA ratio. This reflects that the investment in a company's current assets is lower. Similar steps are taken to separate the companies based on conservative and aggressive financing policies taken.

The company adopts a conservative working capital financing policy (CWCFP) if the $\mathrm{CL} / \mathrm{TA}$ is relatively lower than the industry $\mathrm{CL} / \mathrm{TA}$. This suggests that the company is using relatively lower current liabilities deflated by its total assets. This shows that the company uses fewer short-term debts to finance its current assets. Alternatively, if the company has a higher $\mathrm{CL} / \mathrm{TA}$ relative to the industry $\mathrm{CL} / \mathrm{TA}$, then it is classified as having an aggressive working capital financing policy (AWCFP), the company uses more long-term debt to fund its current assets investments. The independent variables identified for this study are free cash flow, size, growth rate, profitability, leverage and age of the firm. Table 1 shows the measurement of dependent variables and independent variables. 
Table 1:

Proxies and Variable Measurement for Dependent and Independent Variables

\begin{tabular}{|c|c|c|c|}
\hline Variables & Proxy & Measurement & Author (s) \\
\hline \multirow{4}{*}{$\begin{array}{l}\frac{0}{0} \\
\frac{\pi}{0} \\
\frac{0}{2} \\
\frac{\pi}{2} \\
\frac{1}{0} \\
\frac{0}{0} \\
\frac{0}{0} \\
\frac{0}{0} \\
0\end{array}$} & $\begin{array}{l}\text { Conservative } \\
\text { Working Capital } \\
\text { Investment Policy } \\
\text { (CWCIP) }\end{array}$ & $\begin{array}{l}\text { Total current assets / } \\
\text { Total asset > Industry } \\
\text { Mean }\end{array}$ & $\begin{array}{l}\text { Pushpavati and Kamalavalli (2017, } \\
\text { Rosyeni (2017), Salawu and Awolowo } \\
\text { (2007) and Weinraub and Viccsher } \\
\text { (1998). }\end{array}$ \\
\hline & $\begin{array}{l}\text { Aggressive } \\
\text { Working Capital } \\
\text { Investment Policy } \\
\text { (AWCIP) }\end{array}$ & $\begin{array}{l}\text { Total current assets / } \\
\text { Total asset < Industry } \\
\text { Mean }\end{array}$ & $\begin{array}{l}\text { Pushpavati and Kamalavalli (2017, } \\
\text { Rosyeni (2017), Salawu and Awolowo } \\
\text { (2007) and Weinraub and Viccsher } \\
\text { (1998). }\end{array}$ \\
\hline & $\begin{array}{l}\text { Conservative } \\
\text { Working Capital } \\
\text { Financing Policy } \\
\text { (CWCFP) }\end{array}$ & $\begin{array}{l}\text { Total current liabilities/ } \\
\text { Total asset }<\text { Industry } \\
\text { Mean }\end{array}$ & $\begin{array}{l}\text { Pushpavati and Kamalavalli (2017, } \\
\text { Rosyeni (2017), Salawu and Awolowo } \\
\text { (2007) and Weinraub and Viccsher } \\
\text { (1998). }\end{array}$ \\
\hline & $\begin{array}{l}\text { Aggressive } \\
\text { Working Capital } \\
\text { Financing Policy } \\
\text { (AWCFP) }\end{array}$ & $\begin{array}{l}\text { Total current liabilities / } \\
\text { Total asset > Industry } \\
\text { Mean }\end{array}$ & $\begin{array}{l}\text { Pushpavati and Kamalavalli (2017, } \\
\text { Rosyeni (2017), Salawu and Awolowo } \\
\text { (2007) and Weinraub and Viccsher } \\
\text { (1998). }\end{array}$ \\
\hline \multirow{7}{*}{ 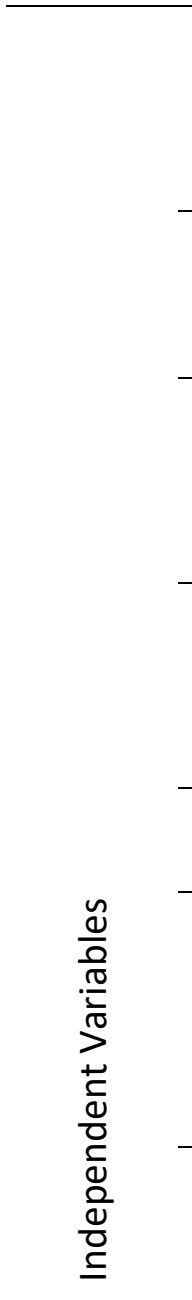 } & $\begin{array}{l}\text { Free Cash Flow } \\
\text { (FCF) }\end{array}$ & $\begin{array}{l}\text { (Income -Tax - Int } \\
\text { Expense- Preferred Stock } \\
\text { Dividend-Common Stock } \\
\text { Dividend) / Total Asset }\end{array}$ & $\begin{array}{l}\text { Palombini \& Nakamura (2012), Haron } \\
\text { \& Nomran (2016) }\end{array}$ \\
\hline & Size (LSIZE) & $\begin{array}{l}\text { Natural Logarithm of } \\
\text { Total assets }\end{array}$ & $\begin{array}{l}\text { Cuong \& Nhung (2017), } \\
\text { Wasiuzzaman and Arumugam (2013), } \\
\text { Zariyawati et al. (2016) }\end{array}$ \\
\hline & $\begin{array}{l}\text { Sales } \quad \text { Growth } \\
\text { (GWTH) }\end{array}$ & $\begin{array}{ll}\text { (Current year sales- } \\
\text { Previous year sale)/ } \\
\text { Previous year sale }\end{array}$ & $\begin{array}{l}\text { Mansoori \& Muhammad (2012), } \\
\text { Zariyawati et al. (2016), Azeem \& } \\
\text { Marsap (2015), Haron \& Nomran } \\
\text { (2016) }\end{array}$ \\
\hline & $\begin{array}{l}\text { Profitability } \\
\text { (PROF) }\end{array}$ & $\begin{array}{l}\text { Operating Profit Margin = } \\
\text { Earnings before Interest } \\
\text { and } \quad \text { Tax } \\
\text { Net sales }\end{array}$ & $\begin{array}{l}\text { Nyeadi et al. (2018), Sharaf \& } \\
\text { Haddad (2015), Haron \& Nomran } \\
\text { (2016) }\end{array}$ \\
\hline & Leverage (LEV) & $\begin{array}{l}\text { Long-term debt /Total } \\
\text { Assets }\end{array}$ & Palombini \& Nakamura (2012) \\
\hline & Age (AGE) & $\begin{array}{l}\text { Date of a company } \\
\text { incorporated until the } \\
\text { end of the year } 2017 \text { and } \\
\text { is a natural logarithm } \\
\text { form. }\end{array}$ & $\begin{array}{l}\text { Chiou et al. (2006), Wasiuzzaman and } \\
\text { Arumugam (2013), Supatanakornkij } \\
\text { (2015) }\end{array}$ \\
\hline & $\begin{array}{ll}\text { Lagged } & \text { CWCIP, } \\
\text { AWCIP, } & \text { CWCFP, } \\
\text { AWCFP } & \end{array}$ & $\begin{array}{l}\text { Lagged } \\
\text { Variables }\end{array}$ & $\begin{array}{l}\text { Banos-Cabarello et al. (2010), Cuong } \\
\text { and Nhung (2017), }\end{array}$ \\
\hline
\end{tabular}


The panel regression method is used to examine the factors influencing the conservative and aggressive working capital investment and financing policies.

$$
\begin{aligned}
& C_{C W I P}{ }_{i, t}=\alpha_{0}+\beta_{1} A G E_{i . t}+\beta_{2} L F C F_{i . t}+\beta_{3} L G R T H_{i . t}+\beta_{4} L L E V_{i . t}+\beta_{5} L P R O F_{i . t}+ \\
& \beta_{6} L S I Z E_{i . t}+\beta_{7} C W C I P_{i . t-1}+\varepsilon_{i, t} \\
& \mathrm{AWCIP} i, t=\alpha_{0}+\beta_{1} A G E_{i . t}+\beta_{2} L F C F_{i . t}+\beta_{3} L G R T H_{i . t}+\beta_{4} L L E V_{i . t}+\beta_{5} L P R O F_{i . t}+ \\
& \beta_{6} L S I Z E_{i . t}+\beta_{7} A W C I P_{i . t-1}+\varepsilon_{i, t} \\
& \mathrm{CWCFP}_{i, t}=\alpha_{0}+\beta_{1} A G E_{i . t}+\beta_{2} L F C F_{i . t}+\beta_{3} L G R T H_{i . t}+\beta_{4} L L E V_{i . t}+\beta_{5} L P R O F_{i . t}+ \\
& \beta_{6} L S I Z E_{i . t}+\beta_{7} C W C F P_{i . t-1}+\varepsilon_{i, t} \\
& A W C F P_{i, t}=\alpha_{0}+\beta_{1} A G E_{i . t}+\beta_{2} L F C F_{i . t}+\beta_{3} L G R T H_{i . t}+\beta_{4} L L E V_{i . t}+\beta_{5} L P R O F_{i . t}+ \\
& \beta_{6} L S I Z E_{i . t}+\beta_{7} A W C F P_{i . t-1}+\varepsilon_{i, t}
\end{aligned}
$$

Where,

$C W C I P_{i, t}=$ Conservative Working Capital Investment Policy for firm $i$ in period $t$

$\mathrm{A} W C I P_{i, t}=$ Aggressive Working Capital Investment Policy for firm $i$ in period $t$

$C W C F P_{i, t}=$ Conservative Working Capital Financing Policy for firm $i$ in period $t$

$\mathrm{AWCFP}_{i, t}=$ Aggressive Working Capital Financing Policy for firm $i$ in period $t$

$i \quad=$ selected sample firms in seven sectors

$t \quad=1,2,3 \ldots .17$ years

$\alpha \quad=$ Constant

$\varepsilon_{i, t} \quad=$ random error term of firm $i$ in period $t$

$\beta_{i} \quad=$ Coefficient

$L F C F_{i . t} \quad=$ Free Cash Flow

LSIZE it $=$ Log Size of Firm

$L G R T H_{i . t}=$ Firm Growth Rate

$L P R O F_{i . t}=$ Profitability Ratio

$L L E V_{i, t} \quad=$ Leverage Ratio

$A G E_{i, t} \quad=$ Age of company

$C W C I P_{i . t-1,}=$ lagged dependent variable $C W C I P_{i, t}$

$A W C I P_{i . t-1}=$ lagged dependent variable $A W C I P_{i, t}$

$C W C F P_{i . t-1,}=$ lagged dependent variable $C W C F P_{i, t}$

$A W C F P_{i . t-1}=$ lagged dependent variable $A W C F P_{i, t}$

Ensuing the studies of Banos-Cabarello et al. (2010), Cuong, and Nhung (2017), this study includes the lagged dependent variables for the respective equations. They claimed that the lagged dependent variable could detect whether the companies have targeted working capital investment policy. If the relationship is positively related, then it shows that a target policy is implemented and therefore the companies will follow the working capital policy consistently. A negative relationship indicates that the companies do not follow the target policy that they have set and deviate from that policy. An insignificant result means that companies do not have any target working capital policy and implement the policy based on the existing condition.

The appropriate panel regression is determined using the Likelihood and Hausman tests. The Likelihood test is conducted to decide if the pooled ordinary least square model or fixed effect model is preferred. If the fixed effect model is chosen, then the Hausman test is estimated to choose between the fixed-effect model or the random-effect model. A randomeffect model is appropriate if the null hypothesis of the Hausman test fails to be rejected. 
MANAGEMENT SCIENCES

Vol. 11, No. 3, 2021, E-ISSN: 2225-8329 @ 2021 HRMARS

\section{Results and Discussion}

Table 2 provides the mean ratios of working capital investment policy (CA/TA) and mean ratios of working capital financial policy (CL/TA) of the trading and services sector for the year 2001 until 2017. On average, the industry means CA/TA and CL/TA ratios for this sector are 0.477 times and 0.284 times respectively.

Table 2: Mean Ratios of CA/TA and CL/TA of Trading and Services Sector for 2001 and 2017

TRADING \& SERVICES SECTOR

\begin{tabular}{lll}
\hline $\operatorname{ar}$ & $\begin{array}{l}\text { WCIP } \\
\text { (CA/TA) }\end{array}$ & $\begin{array}{l}\text { WCFP } \\
\text { (CL/TA) }\end{array}$ \\
\hline 101 & 484 & 0.337 \\
\hline 102 & 468 & 0.295 \\
\hline 103 & 474 & 0.293 \\
\hline 104 & 479 & 0.294 \\
\hline 105 & 472 & 0.293 \\
\hline 106 & 478 & 0.315 \\
\hline 107 & 499 & 0.283 \\
\hline 108 & 477 & 0.273 \\
\hline 109 & 473 & 0.271 \\
\hline 10 & 475 & 0.270 \\
\hline 11 & 474 & 0.275 \\
\hline 112 & 495 & 0.281 \\
\hline 13 & 483 & 0.263 \\
\hline 14 & 478 & 0.262 \\
\hline 15 & 474 & 0.276 \\
\hline 16 & 472 & 0.271 \\
\hline 117 & 460 & 0.300 \\
\hline Industry Mean & 477 & 0.284 \\
\hline
\end{tabular}

Table 3 displays the number of trading and services companies that adopt CWCIP, AWCIP, CWCFP and AWCFP. For working capital investment policy about $51.5 \%$ of the companies in the sector resort to conservative policy relative to aggressive policy. This signifies that a majority of the trading and services companies have a higher investment in current assets. Nyeadi et al. (2018) pointed out that trading and services companies normally maintained a sizeable amount of cash, inventories and account receivables. In addition, the companies also want to avoid production disruptions, risk of stock-out, increase in supply costs and price volatility. Concerning working capital financing policy, about 80 companies (59.7\%) use more long-term financing as opposed to about $40.3 \%$ of them that prefer to source funds on a shortterm basis. Chiou et al. (2006) explain that highly levered companies denote inadequate internal funds for day-to-day operations. 
INTERNATIONAL JOURNAL OF ACADEMIC RESEARCH IN ACCOUNTING, FINANCE AND MANAGEMENT SCIENCES

Vol. 11, No. 3, 2021, E-ISSN: 2225-8329 @ 2021 HRMARS

Table 3:

Number of Trading Companies based Working Capital Investment and Financing Policies

\begin{tabular}{l|l|l|l|l|l}
\hline \multirow{2}{*}{ Total } & \multicolumn{2}{|l|}{$\begin{array}{l}\text { Working Capital Investment } \\
\text { Policy } \\
\text { CA/TA) }\end{array}$} & $\begin{array}{l}\text { Working Capital Financing } \\
\text { Policy } \\
\text { (CL/TA) }\end{array}$ \\
\cline { 3 - 6 } & & CWCIP & AWCIP & CWCFP & AWCFP \\
\hline \multirow{2}{*}{ Trading \& Services } & \multirow{2}{*}{134} & 69 & 65 & 80 & 54 \\
\cline { 3 - 6 } & $51.5 \%$ & $48.5 \%$ & $59.7 \%$ & $40.3 \%$ \\
\hline
\end{tabular}

The Levin, Lin and Chu unit root tests in Table 4 above revealed that all variables for AWCIP, CWCFP and AWCFP are stationary at the level since the study failed to reject the null hypothesis of the presence of unit root. As for CWCIP, leverage and size variables are not stationary at the level since the alternate hypothesis of no unit root is accepted. After first differencing these independent variables, this study accepts the alternative hypothesis, indicating there is no unit root. 
INTERNATIONAL JOURNAL OF ACADEMIC RESEARCH IN ACCOUNTING, FINANCE AND MANAGEMENT SCIENCES

Vol. 11, No. 3, 2021, E-ISSN: 2225-8329 @ 2021 HRMARS

Table 4:

Summary of the Levin, Lin and Chu Unit Root Tests for the Variables

\begin{tabular}{|c|c|c|c|c|c|c|c|c|}
\hline \multirow[b]{2}{*}{ VARIABLES } & \multicolumn{2}{|l|}{ CWCIP } & \multicolumn{2}{|l|}{ AWCIP } & \multicolumn{2}{|l|}{ CWCFP } & \multicolumn{2}{|l|}{ AWCFP } \\
\hline & LEVEL & $\begin{array}{l}1^{\text {ST }} \\
\text { DIFF }\end{array}$ & LEVEL & $\begin{array}{l}1^{\text {ST }} \\
\text { DIF } \\
\text { F } \\
\end{array}$ & LEVEL & $\begin{array}{l}1^{\text {ST }} \\
\text { DIF } \\
F\end{array}$ & LEVEL & $\begin{array}{l}1^{\text {ST }} \\
\text { DIFF }\end{array}$ \\
\hline $\begin{array}{l}\text { CWCIP/AWCI } \\
\text { P/CWCFP/A } \\
\text { WCFP }\end{array}$ & $\begin{array}{l}- \\
2.2041^{* *} \\
* \\
0.0138\end{array}$ & na & $\begin{array}{l}- \\
7.3082 * \\
* * \\
0.0000\end{array}$ & na & $\begin{array}{l}- \\
16.6746 \\
* * * \\
0.0000\end{array}$ & na & $\begin{array}{l}- \\
8.2027^{*} \\
* * \\
0.0000\end{array}$ & na \\
\hline AGE & $\begin{array}{l}- \\
119.488 * \\
* * \\
0.0000\end{array}$ & na & $\begin{array}{l}- \\
9.8450 * \\
* * \\
0.0000\end{array}$ & na & $\begin{array}{l}- \\
15.0633 \\
* * * \\
0.0000\end{array}$ & na & $\begin{array}{l}- \\
7.5410 * \\
* * \\
0.0000\end{array}$ & na \\
\hline FCF & $\begin{array}{l}- \\
14.5431 * \\
* * \\
0.0000\end{array}$ & na & $\begin{array}{l}- \\
10.8598 \\
* * * \\
0.0000\end{array}$ & na & $\begin{array}{l}- \\
10.7808 \\
* * * \\
0.0000\end{array}$ & na & $\begin{array}{l}- \\
16.7777 \\
* * * \\
0.0000\end{array}$ & na \\
\hline GRTH & $\begin{array}{l}- \\
28.2261 * \\
* * \\
0.0000\end{array}$ & na & $\begin{array}{l}- \\
31.9265 \\
* * * \\
0.0000\end{array}$ & na & $\begin{array}{l}- \\
39.3663 \\
* * * \\
0.0000\end{array}$ & na & $\begin{array}{l}- \\
133.740 \\
* * * \\
0.0000\end{array}$ & na \\
\hline LEV & $\begin{array}{l}11.3860 \\
1.0000\end{array}$ & $\begin{array}{l}- \\
22.2596 * * \\
* \\
0.0000\end{array}$ & $\begin{array}{l}- \\
18.7295 \\
* * * \\
0.0000\end{array}$ & na & $\begin{array}{l}- \\
948.332 \\
* * * \\
0.0000\end{array}$ & na & $\begin{array}{l}- \\
7.9329 * \\
* * \\
0.0000\end{array}$ & na \\
\hline PROF & $\begin{array}{l}- \\
6.6871^{* *} \\
* \\
0.0000\end{array}$ & na & $\begin{array}{l}- \\
9.6458 * \\
* * \\
0.0000\end{array}$ & na & $\begin{array}{l}- \\
8.4833^{*} \\
* * \\
0.0000\end{array}$ & na & $\begin{array}{l}- \\
6.1563^{*} \\
* * \\
0.0000\end{array}$ & na \\
\hline LSZE & $\begin{array}{l}8.2267 \\
1.0000\end{array}$ & $\begin{array}{l}25.1500 * * \\
* \\
0.0000\end{array}$ & $\begin{array}{l}- \\
8.0361 * \\
* * \\
0.0000\end{array}$ & na & $\begin{array}{l}- \\
8.7732 * \\
* * \\
0.0000\end{array}$ & na & $\begin{array}{l}- \\
4.8275^{*} \\
* * \\
0.0000\end{array}$ & na \\
\hline
\end{tabular}

Note: $* * *, * *$ and $*$ denote $1 \%, 5 \%$ and $10 \%$ significant level

\section{Results of the Likelihood Test and Hausman Test}

Likelihood and Hausman tests are carried out to determine the appropriate panel regression models (Table 5). For CWCIP, the most appropriate regression models are pooled ordinary least square (POLS) models since the results of the chi-square from the Likelihood test are not statistically significant. This shows that researchers fail to reject the null hypothesis that POLS is the appropriate model. Random Effect models are most suitable for AWCIP, CWCFP and AWCFP.F since the chi-square statistic for Hausman tests is not statistically significant. 
INTERNATIONAL JOURNAL OF ACADEMIC RESEARCH IN ACCOUNTING, FINANCE AND MANAGEMENT SCIENCES

Vol. 11, No. 3, 2021, E-ISSN: 2225-8329 @ 2021 HRMARS

Table 5

Test Summary of Likelihood and Hausman Tests for four-panel regression models

\begin{tabular}{lllll} 
& CWCIP & AWCIP & CWCFP & AWCFP \\
\hline Likelihood Test (Chi-Sq) & 0.0000 & $397.1726^{* * * *}$ & $840.2813^{* * * *}$ & $397.1726^{* * *}$ \\
\hline $\begin{array}{l}\text { Ho: POLS } \\
\text { Ha : FE }\end{array}$ & POLS & FE & FE & FE \\
\hline $\begin{array}{llll}\text { Hausman Test (Chi-Sq) } \\
\text { Ho: RE }\end{array}$ & na & 0.0000 & 0.0000 & 0.0000 \\
Ha: FE & na & RE & RE & RE \\
\hline Model & POLS & RE & RE & RE \\
\hline
\end{tabular}

*** Significant at $1 \%$ level

\section{Results of the Estimated Regression Models}

Table 6 presents the estimated results of the regression models for CWCIP, AWCIP, CWCFP and AWCFP respectively.

Table 6

Estimated Panel Date Regression Results of CWCIP, AWCIP, CWCIP and AWCIP

\begin{tabular}{|c|c|c|c|c|}
\hline Equation (Model) & $1 a$ & $1 b$ & 1c & 1d \\
\hline \multicolumn{2}{|c|}{ Dependent VariableCWCIP } & AWCIP & CWCFP & AWCFP \\
\hline $\begin{array}{l}\text { Independent } \\
\text { Variables }\end{array}$ & $\begin{array}{l}\text { Coef } \\
\text { p-value }\end{array}$ & $\begin{array}{l}\text { Coef } \\
\text { p-value }\end{array}$ & $\begin{array}{l}\text { Coef } \\
\text { p-value }\end{array}$ & $\begin{array}{l}\text { Coef } \\
\text { p-value }\end{array}$ \\
\hline AGE & $\begin{array}{l}0.0267^{* * *} \\
0.0000\end{array}$ & $\begin{array}{l}0.0077 \\
0.2445\end{array}$ & $\begin{array}{l}-0.0033 \\
0.3698\end{array}$ & $\begin{array}{l}-0.0063 \\
0.4608\end{array}$ \\
\hline LFCF & $\begin{array}{l}1.1601^{* * *} \\
0.0000\end{array}$ & $\begin{array}{l}0.0177 \\
0.1931\end{array}$ & $\begin{array}{l}-4.58 E-06 * \\
0.0568\end{array}$ & $\begin{array}{l}-0.1126^{* * *} \\
0.0061\end{array}$ \\
\hline LGRTH & $\begin{array}{l}-0.0008^{* * *} \\
0.0000\end{array}$ & $\begin{array}{l}-0.0008 \\
0.7715\end{array}$ & $\begin{array}{l}0.0014 \\
0.4509\end{array}$ & $\begin{array}{l}-0.0005^{*} \\
0.0611\end{array}$ \\
\hline LLEV & $\begin{array}{l}-752.6376 * * * \\
0.0000\end{array}$ & $\begin{array}{l}-0.1589 * * * \\
0.0000\end{array}$ & $\begin{array}{l}-0.0601 * * \\
0.0448\end{array}$ & $\begin{array}{l}-0.4302^{* * *} \\
0.0000\end{array}$ \\
\hline LPROF & $\begin{array}{l}-0.0006 * * * \\
0.0005 \\
\end{array}$ & $\begin{array}{l}-5.61 E-09 \\
0.6750 \\
\end{array}$ & $\begin{array}{l}1.60 \mathrm{E}-08 \\
0.1313 \\
\end{array}$ & $\begin{array}{l}-0.0001^{*} \\
0.0527\end{array}$ \\
\hline LSZE & $\begin{array}{l}-0.0655^{* * *} \\
0.0000\end{array}$ & $\begin{array}{l}-0.0053 \\
0.1074\end{array}$ & $\begin{array}{l}0.0040 * * \\
0.0159\end{array}$ & $\begin{array}{l}0.0096 * * * \\
0.0092\end{array}$ \\
\hline Lagged DV & $\begin{array}{l}0.6411 * * * \\
0.0000\end{array}$ & $\begin{array}{l}0.5851 * * * \\
0.0000\end{array}$ & $\begin{array}{l}0.5952 * * * \\
0.000\end{array}$ & $\begin{array}{l}0.7060 * * * \\
0.0000\end{array}$ \\
\hline
\end{tabular}




\begin{tabular}{|c|c|c|c|c|}
\hline C & $\begin{array}{l}0.6945^{* * *} \\
0.0000\end{array}$ & $\begin{array}{l}0.2096 * * * \\
0.0000\end{array}$ & $\begin{array}{l}0.03619 * \\
0.0708\end{array}$ & $\begin{array}{l}0.0560 \\
0.3526\end{array}$ \\
\hline \multicolumn{2}{|c|}{ Adjusted R-Squared 0.6424} & 0.4537 & 0.3827 & 0.6006 \\
\hline F-statistic & $331.2052 * * *$ & $114.3070 * * *$ & $102.2195^{* * *}$ & $166.4346 * * *$ \\
\hline DW Stat & 1.8553 & 2.0870 & 1.8684 & 2.0629 \\
\hline Model & POLS & RE & RE & RE \\
\hline
\end{tabular}

\section{Driving Factors of CWCIP}

For equation $1 \mathrm{a}$, where CWCIP is the dependent variable, all the independent variables identified are statistically significant at a $1 \%$ confidence level. Age and free cash flow are a positive relationship with CWCIP, while growth rate, leverage, profitability and size are inversely related. It seems that older small companies with high free cash flow but lower growth rate, less levered and lower profitability ratio tend to adopt a higher degree of current ratio to total assets. The reason for having relatively higher investment in current assets is because these companies existed for so many years and therefore have excess retained capital and have the bargaining power to negotiate with their suppliers (Wasiuzzaman, \& Arumugam, 2013). A positive relationship between FCF and CWCIP is in line with the pecking order theory advocated by Myers and Majluf (1984). It denotes that companies with higher cash flow can afford to invest more in current assets since they have a high amount of internal funding. The findings are parallel with those of Banos-Caballero et al (2010) and Wasiuzzaman, and Arumugam (2013). The inverse relationship between growth rate and CWCIP implies that lower growth companies prefer to follow conservative working capital investment policy. This is in harmony with the findings of Nyedia et al. (2018) where they explained that when companies experienced lower sales growth, they put high commitment into current assets instead of fixed assets. A negative relationship between profitability and CWCIP implicates profitable companies prefer conservative working capital policy, they invest in short-term investments assets rather than long-term investments. Nyeadi et al. (2018) pointed out that the nature of the business that the firm is in will determine the level of investments in current assets. The authors further mentioned that trading and services companies normally maintained a sizeable amount of cash, inventories and account receivables.

Furthermore, they claimed that such a move only indicates the management interest in pursuing short-term goals which conflict with the interest of the companies. This action matches with the agency theory proposed by Jensen and Meckling (1976). An inverse relationship between LEV and CWCIP is best explained using the Pecking order theory. Pecking order theory explained that firms could choose their internal fund or retained earnings before turning into debt as an option to source funds. This is because external financing is costly due to issuing costs as well as tight monitoring from investors. Another independent variable that is negatively related to CWCIP is size. Findings show that smaller companies in the trading and service sector seek to pursue CWCIP because they have limited access to and cheaper financial sources. Morris and Payne (2011) pointed out that since small companies are more vulnerable during economic turbulence and have fewer financing options, they are conservative in managing their current assets and thus resort to spend more on working 
MANAGEMENT SCIENCES

Vol. 11, No. 3, 2021, E-ISSN: 2225-8329 @ 2021 HRMARS

capital. This is also in harmony with the studies of Azeem and Marsap (2015), and Cuong and Nhung (2017). This verifies with the pecking order theory of Myers (1984), agency theory and free cash flow hypothesis of Jensen (1986).

\section{Driving Factors of AWCIP}

Leverage is the only driving factor for companies in this sector to apply aggressive working capital investment policy (AWCIP) and the relationship is inversely related. This suggests that highly geared companies choose to maintain a lower degree of current assets investment. The plausible explanation is that using long-term debt to finance their current assets could be costly and therefore management is compelled to manage efficiently their current asset investments to prevent sourcing additional external funding (Banos-Caballero et al., 2013, Rosyeni, 2017 and Supatanakornkij, 2014). Besides, Zariyawati et al., (2010) also put forward that management has to cautiously manage its working capital since the lender and shareholders are observing them if they are highly levered. This is in support of agency theory.

\section{Driving Factors of CWCFP}

Free cash flow, leverage and size are the only driving factors for adopting a conservative working capital financing policy (CWCFP). As shown in the table, both LFCF and LLEV variables are negatively related to CWCFP. However, LFCF is statistically significant at the $10 \%$ level while LLEV and LSIZE are statistically significant at the $5 \%$ level. As companies have more free cash flow, they are less inclined to adopt a high degree of conservative working capital financing policy. With excessive cash flow, companies can use the cash to finance the investment of their current assets and therefore reduces higher capital costs. Obuya (2017) argued that because of the high cost of using long-term debts, having cash or having trade credit is an advantage to the companies. This shows that highly geared companies will be less conservative in their financing policy to meet their current assets requirement. The plausible reason is that the company will put itself at higher risk that would lead to financial distress if it continues to finance its current assets investments with long-term debt. Therefore, to mitigate this risk, the management will need to depend on more internal financing which is less costly (Elbadry, 2018; Nyeadi et al., 2018). Finally, size has a direct significant relationship with conservative working capital financing policy. This is in line with the trade-off theory that pointed out larger companies usually can tolerate a higher debt ratio, and therefore can easily pay for investment in working capital (Onaolapo and Kajola, 2015).

\section{Driving Forces of AWCFP}

Free cash flow and leverage are statistically and inversely linked to AWCFP at a $1 \%$ significant level. This suggests that companies with high cash holdings will not resort to internal funding to finance their working capital requirement but use external sources of funds like long-term debt (Hill et al., 2010). The rationale behind it is because they have enough cash to pay for the interest obligations incurred. Besides, companies that are highly levered tend to use less short-term liabilities to meet their current asset needs. This shows the companies pay their current asset investment using prospective term debt rather than matching it with their account payables and short-term loans On the other hand, size has a strong positive relationship with the decision of the companies to be aggressive in their financing policy. This posits that larger companies prefer to have an aggressive financing policy to pay for their investment in current assets. Wasiuzzaman and Arumugam (2013) 
MANAGEMENT SCIENCES

Vol. 11, No. 3, 2021, E-ISSN: 2225-8329 @ 2021 HRMARS

argued that the financial decision taken by management could be due to either the companies do not have a specific debt-equity ratio, or these companies have surplus internal funds. This is in line with the Myers and Majluf (1984) pecking order theory.

Growth rate and profitability are also negatively related to AWCFP but only at $10 \%$. This denotes that companies facing a high growth rate will most likely have a less aggressive working capital financing strategy. Hill, Kelly and Highfield (2010) argue that when companies face a higher growth rate in sales, instead of relying more on their account payables, will choose to use their external financing. There is a possibility that a less profitable company is unlikely to use short-term financing because the company has already an enormous amount of funds tied up in trade debtors that could lead to strain on cash flow demands (Otto, 2018). As a result, the company has no choice but to resort to long-term debt instead.

As revealed in Table 6 above, all the lagged dependent variables are positive and statistically significantly related to the respective dependent variables. This implies that the companies have established a targeted conservative/aggressive investment and financing policies and are pursuing them consistently (Cuong \& Nhung, 2017). With exception to the lagged dependent variable, the driving factors affecting the working capital management and financing policies differ.

\section{Conclusion and Recommendation}

This paper aims to examine the driving factors affecting Trading and Services companies to adopt conservative or aggressive working capital investment and financing policies. It differs from previous studies as it separated accordingly the dependent variables into conservative and aggressive investment and financing policies. This facilitates an in-depth understanding of the factors affecting the adoption of such policies. Age, growth rate, leverage, profitability, free cash flow, size and lagged dependent variables are used. The results of the panel regression analysis furnish this conclusion. Empirically the study reveals that all the identified independent variables are the driving factors for companies to apply conservative working capital investment policy. Only leverage is inversely related to CWCIP, AWCIP, CWCFP and AWCFP. All trading and services companies seem to practice a targeted conservative/aggressive investment and financing policies since the lagged dependent variables are positive and statistically significant. Based on previous studies, attention related to this area is mainly on the relationship between working capital management on firm performance. Hence, this paper enhances the existing growing and scarce literature on the determinants of working capital investment and financing policies. It also enables managers to have a better understanding of the rationale for using specific working capital policies. Future research could examine the impact of working capital investment and financing policies on company performance and firm values. Another area of study to be explored is to investigate if the industry effect could affect the adoption of working capital investment and financing policies.

\section{References}

Appuhami, B. A. R. (2008). The Impact of Firms' Capital Expenditure on Working Capital Management: An Empirical Study across Industries in Thailand. International Management Review, 4(1), 8-20.

Ashhari, Z. M., Hassan, T., \& Nassir, A. M. (2010). Determinants of Working Capital Management: Evidence From Malaysia. Journal of Modern Accounting and Auditing, 5(11), 47-54. 
MANAGEMENT SCIENCES

Vol. 11, No. 3, 2021, E-ISSN: 2225-8329 ๔ 2021 HRMARS

Azeem, M. M., \& Marsap, A. (2015). Determinants Factors and Working Capital Requirement. International Journal of Economics and Finance, 7(2), 280-292.

Bandara, R. M. S. (2015). Impact of Working Capital Management Policy on Market Value Addition. Global Journal of Contemporary Research in Accounting, Auditing and Business Ethics (GJCRA). 1(2), 354-373.

Banos-Caballero, S., Garcia-Teruel, P. J., \& Martinez-Solano, P. (2010). Working Capital Management in SMEs. Accounting and Finance, (50), 511-527.

Chiou, J-R., Cheng, L., \& Wu, H-W. (2006). The Determinants of Working Capital Management, Journal of American Academy of Business, 10(1), 149-155.

Cuong, N. T., \& Nhung, N. T. H. (2017). Determinants of Working Capital Requirement: Evidence from Non-Financial Firms Listed on the Vietnam Exchange. Journal of Insurance and Financial Management, 3(1), 19-29.

Crump, R. (2012). REL Working Capital Survey 2012 [Online]. Retrieved October 10, 2017, from the World Wide Web: http://www.financialdirector.co.uk/financialdirector/research/2201152/rel working-capital-survey-2012.

Ebenezer, A. B., \& Asiedu, M. K. (2013). The Relationship between Working Capital Management and Profitability of Listed Manufacturing Companies in Ghana. International Journal of Business and Social Research, 3(2), 25-34.

Elbadry, A. (2018). The Determinant of Working Capital Management in the Egyptian SMEs. Accounting and Finance Research, 7(2), 155-165.

Ernst \& Young. (2016). All Tied Up Working Capital Management Report 2016. UK: Ernst \& Young Global Limited.

Fatimatuzzahra, M., \& Kusumastuti, R. (2016). The Determinant of Working Capital Management of Manufacturing Companies. Mimbar: Jurnal Sosial dan Pembangunan, 32(2), 276-281.

Ferreira, M. A., \& Vilela, A. S. (2004). Why do Firms Hold Cash? Evidence from EMU Countries. European Financial Management, 10(2), 295-319.

Garcia-Teruel, P. J., \& Martinez-Solano, P. (2007). Effects of Working Capital Management on SME Profitability. International Journal of Managerial Finance, 3(2), 164-177.

Gill, A. S., \& Biger, N. (2013). The Impact of Corporate Governance on Working Capital Management Efficiency of American Manufacturing, Managerial Finance, 39(2), 116 132.

Haron, R., \& Nomran, N. M. (2016). Determinants of Working Capital Management Before, During and After the Global Financial Crisis of 2008: Evidence from Malaysia. The Journal of Developing Areas, 50(5), 461-468.

Hassan, N. U., Imran, M. M., Amjad, M., \& Hussain, M. (2014). Effect of Working Capital Management on Firm Performance: An Empirical Study of Non-financial listed Firms in Pakistan. International Journal of Academic Research in Business and Social Sciences, 4(6), 114-132.

Hill, M. D., Kelly, G. W., \& Highfield M. J., 2010. Net Operating Working Capital Behavior: A First Look. Financial Management, 783-805.

Iftikhar, M. F. (2013). Determinants of Working Capital Management Efficiency: Case Study of Pakistani Automotive and Engineering Firms Listed in Karachi Stock Exchange. Research Journal of Finance and Accounting, 4(7), 216-236.

Javid, S., \& Zita, V. P. M. (2014). Impact of Working Capital Policy on Firm's Profitability: A Case of Pakistan Cement Industry. Research Journal of Finance and Accounting, 5(5), 182-191. 
MANAGEMENT SCIENCES

Vol. 11, No. 3, 2021, E-ISSN: 2225-8329 @ 2021 HRMARS

Jensen, M. (1986). Agency costs of free cash flow, corporate finance, and takeovers, American Economic Review, 76, 323-329.

Jensen, M. (1989). Eclipse of the Public Corporation, Harvard Business Review, 67, 61- 74.

Jensen, M., \& Meckling, W. (1976). Theory of the firm: managerial behaviour, agency costs and ownership structure, Journal of Financial Economics, 3, 305-360.

Kasiran, F. W., Mohamad, N. A., \& Chin, O. (2016). Working Capital Management Efficiency: A Study on the Small Medium Enterprises in Malaysia. Procedia Economics and Finance, (35), 297-303.

Keown, A. J., Martin, J. D., Petty, J. W., \& David. (2007). Foundations of Finance (Sixth Edition ed.): Pearson Prentice Hall.

Khan, M. N., Rasheed, S., Ahmed, H. I., \& Rizwan, M. (2016). Impact of Working Capital Management on Firm Financial Performance: An Empirical Evidence from Non-Financial Sector of Pakistan. International Journal of Advanced Scientific Research and Management Finance and Accounting, 1(5), 150-158.

Lamberson, M. (1995). Changes in Working Capital of Small Firms in Relation to Changes in Economic Activity. American Journal of Business, 10(2), 45-50.

Mansoori, E., \& Muhammad, J. (2012). Determinants Working Capital Management: Case of Singapore Firms. Research Journal of Finance and Accounting, 3(11), 15-23.

Mathuva, D. M. (2014). The Influence of Working Capital Management Components on Corporate Profitability: A Survey on Kenyan Listed Firms. Research Journal of Business Management 4(1), 1-11.

McMahon, R. G. P. (2006). Financial Slack Amongst Manufacturing SMEs from Australia's Business Longitudinal Survey: An Exploratory Study. Small Enterprise Research, 14(1), 14-38.

Mohamad, N. E. A., \& Elias, S. B. (2013). An Assessment on Determinant of Working Capital Management from Malaysian Public Listed Companies. International Journal of Academic Research in Accounting, Finance and Management Sciences, 3(4), 224-228.

Moussawi, R., LaPlante, M., Kieschnick, R., \& Baranchuk, N. (2006), Corporate Working Capital Management: Determinants and Consequences, Working paper, viewed 20 February 2018 http://www.fma.org/SLC/Papers/cwcmf_fma.pdf

Moradi, M., Salehi, M., \& Arianpoor, A. (2012). A Comparison of Working Capital Management of Chemical and Medicine Listed Companies in Tehran Stock Exchange. International Journal of Business and Behavioral Science, 2(5), 62-78.

Morris, J., \& Payne, S. (2011). Size Matters in Working Capital. Capital Agenda Insights, November, 1-4.

Myers, S. C., \& Majluf, N. S. (1984). Corporate Financing and Investment Decisions When Firms Have Information that Investors Do Not Have. Journal of Financial Economics, 13(2), 187-221.

Nazir, M. S., \& Afza, T. (2009). Working capital requirements and the determining factors in Pakistan. IUP Journal of Applied Finance, 2(4), 28-38.

Ng, S. H., Ye, C., Ong, T. S., \& Teh, B. H. (2017). The Impact of Working Capital Management on Firm's Profitability: Evidence from Malaysian Listed Manufacturing Firms, International Journal of Economic and Financial Issues, 7(3), 662-670.

Nguyen, H-C., Tran, M-D., \& Nguyen, D-T. (2016). Working Capital Management and Firms' Profitability: Evidence from Vietnam's Stock Exchange, International Journal of Economics and Finance, 8(5), 55-56 
MANAGEMENT SCIENCES

Vol. 11, No. 3, 2021, E-ISSN: 2225-8329 ๔ 2021 HRMARS

Nyeadi, J. D., Sare, Y. A., \& Aawaar, G. (2018). Determinants of Working Capital Requirement in Listed Companies at the Nairobi Securities Exchange: Empirical Evidence Using a Dynamic System GMM. Cogent Economics \& Finance, 6(1), 1-14.

Obuya, D. O. (2017). Debt Financing Option and Financial Performance of Micro and Small Enterprises: A Critical Literature Review. International Journal of Business and Management, 12(3), 221-231.

Onaolapo, A. A., \& Kajola, S. O. (2015). What are the Determinants of Working Capital Requirements of Nigerian Firms? Research Journal of Finance and Accounting, 6(6), 118127.

Otto, W. H. (2018). Management of Trade Credit by Small and Medium-sized Enterprises. Journal of Economic and Financial Sciences, 11(1), 1-8.

Ozkan, A., \& Ozkan, N. (2004). Corporate Cash Holdings: An Empirical Investigation of UK Companies. Journal of Banking and Finance, 28, 2103-2134.

Pais, M. A., \& Gama, P. G. (2015). Working Capital Management and SMEs Profitability: Portuguese Evidence. International Journal of Managerial Finance, 11(3), 341-358.

Palombini, N. V. N., \& Nakamura, W. T. (2012). Key Factor in Working Capital Management in the Brazilian Market. Revista de Administração de Empresas. 52(1), 55-69.

Panigrahi, A. K. (2014). Case Study Understanding the Working Capital Financing Policy (A Case Study of Lupin Limited). Journal of Management Research \& Analysis, 1(1), 108-120.

Price Waterhouse Corporation. (2019). Working Capital Report 2019/20. Creating value through working capital.

https://www.pwc.com/gx/en/services/deals/business-recoveryrestructuring/working-capital-opportunity.html

Pushpavathi, S., \& Kamalavalli, A. L. (2017). Industry Practice Relating to Aggressive Conservative Working Capital Policies: An Empirical Study on Indian Pharmaceutical Companies. International Journal of Multidisciplinary Research and Modern Education, 3(1), 421-426.

Rosyeni, R. (2017). Impact of the Aggressive Working Capital Management Policy on Firm's Profitability and Value: Study on Non-Financial Listed Firms in Indonesia Stock Exchange. Advances in Economics, Business and Management Research, 36, 207-216.

Salawu, R. O., \& Awolowo, O. (2017). Capital Industry Practice and Aggressive Conservative Working Capital Policies in Nigeria. Global Journal of Business Research, 1(2), 109-117.

Shin, H-H., \& Soenen, L. (1998). Efficiency of Working Capital Management and Corporate Profitability. Financial Practice and Education, 8(2), 37- 45.

Singh, H. P., \& Kumar, S. (2014). Working Capital Management: A Literature Review and Research Agenda. Qualitative Research in Financial Market, 6(2), 173-197.

SSupatanakornkij, S. (2014). The Determinants of Working Capital Management: Evidence from European Companies. 4th Annual International Conference on Accounting and Finance (AF 2014). 151-154.

Supatanakornkij, S. (2015). The Determinants and Consequences of Working Capital Management: Phd in Accounting Thesis. University of Edinburgh. Retrieved January 1, 2017, from the World Wide Web:

https://pdfs.semanticscholar.org/1f69/fd7597855e7294f2bf790b9b167e0597b20b.pd f.

Temtime, Z. T. (2016). Relationship between Working Capital Management, Policies, and Profitability of Small Manufacturing Firms. Dissertation of Doctor of Business Administration. Walden University. Retrieved January 1, 2017, from www.http:// 
scholarworks. waldenu.edu/cgi/viewcontent.cgi?article=3208\&context=dissertations.

Wasiuzzaman, S., \& Arumugam, V. C. (2013). Determinants of Working Capital Management: A study of Malaysian Public Listed Firms. Australasian Accounting Business and Finance Journal, 7(1), 49 - 69.

Weinraub, H. J., \& Visscher, S. (1998). Industry Practice Relating to Aggressive Conservative Working Capital Policies. The Journal of Financial and Strategic Decisions, 11 (2), 11-18.

Zariyawati, M. A., Annuar, M. N., Taufiq, H., \& Sazali, A. (2010). Determinants of Working Capital Management: Evidence from Malaysia. International Conference on Financial Theory and Engineering. 190-194.

Zariyawati, M. A., Annuar, M. N., \& Pui-San, N. (2016). Working Capital Determinants of Small and Large Firms in Malaysia. International Journal of Economics and Management, 10(2), 365-377. 